\title{
Correction: changes in the lifetime prevalence of suicidal feelings and thoughts among Norwegian doctors from 2000 to 2010: a longitudinal study based on national samples
}

Judith Rosta ${ }^{1 *}$ and Olaf G Aasland ${ }^{1,2}$

\section{Correction}

After the publication of this work [1], we became aware of some typing errors. The correct spelling of the item 3 on page 3 was "Have you ever thought of taking your own life, even if you would not really do it?", and not "Have you ever through of taking your own life, even if you would not really do it?" The correct typing of the sentence on page 6 , line 1 was "never" $=0$, "hardly ever", "sometimes" or "often" $=1$, and not "never" or "hardly ever" $=0$, "sometimes" or "often" $=1$. We apologise for any inconvenience these may have caused.

\section{Author details \\ ${ }^{1}$ Institute for Studies of the Medical Profession (LEFO), Norwegian Medical Association, PO Box 1152 Sentrum, 0107 Oslo, Norway. ${ }^{2}$ Institute of Health and Society, Department of Health Management and Health Economics, University of Oslo, Oslo, Norway.}

Received: 17 December 2013 Accepted: 18 December 2013 Published: 2 January 2014

\section{Reference}

1. Rosta J, Aasland OG: Changes in the lifetime prevalence of suicidal feelings and thoughts among Norwegian doctors from 2000 to 2010: a longitudinal study based on national samples. BMC Psychiatry 2013, 13:322.

\section{doi:10.1186/1471-244X-14-1}

Cite this article as: Rosta and Aasland: Correction: changes in the lifetime prevalence of suicidal feelings and thoughts among Norwegian doctors from 2000 to 2010: a longitudinal study based on national samples. BMC Psychiatry 2014 14:1.

\footnotetext{
* Correspondence: judith.rosta@legeforeningen.no

${ }^{1}$ Institute for Studies of the Medical Profession (LEFO), Norwegian Medical

Association, PO Box 1152 Sentrum, 0107 Oslo, Norway

Full list of author information is available at the end of the article
}

\section{Submit your next manuscript to BioMed Central and take full advantage of:}

- Convenient online submission

- Thorough peer review

- No space constraints or color figure charges

- Immediate publication on acceptance

- Inclusion in PubMed, CAS, Scopus and Google Scholar

- Research which is freely available for redistribution

Submit your manuscript at

www.biomedcentral.com/submit

C Biomed Central

C Biomed Central

(c) 2014 Rosta and Aasland; licensee BioMed Central Ltd. This is an Open Access article distributed under the terms of the Creative Commons Attribution License (http://creativecommons.org/licenses/by/2.0), which permits unrestricted use, distribution, and reproduction in any medium, provided the original work is properly cited. The Creative Commons Public Domain Dedication waiver (http://creativecommons.org/publicdomain/zero/1.0/) applies to the data made available in this article, unless otherwise stated. 